\title{
Decomposition of Thioureas by a Penicillium Species and Soil and Sewage-sludge Microflora
}

\author{
By E. S. LASHEN* AND R. L. STARKEY \\ Department of Biochemistry and Microbiology, College of Agriculture \\ and Environmental Science, Rutgers, The State University, New Brunswick, \\ New Jersey 08903, U.S.A.
}

(Accepted for publication 6 October 1970)

\begin{abstract}
SUMMARY
A Penicillium species isolated from soil, decomposed up to $0 \cdot 1 \%(\mathrm{w} / \mathrm{v})$ thiourea only with an energy source such as glucose. The fungus released part of the sulphur and nitrogen as sulphate and ammonia which served as $\mathrm{S}$ and $\mathrm{N}$ sources. The medium became strongly acid due to organic acids originating from glucose; at the acid reactions the amount of sulphate formed was small, but near neutrality most of the sulphur was oxidized to sulphate. Most decomposition of the thiourea and production of sulphate and acid occurred during the lag phase. Ammonium nitrogen promoted growth but reduced decomposition of thiourea. Nitrate was assimilated in the absence of thiourea but not in its presence. Citrate did not support growth but promoted assimilation of nitrogen. Glucose augmented from 0.2 to $2.0 \%$ led to increased growth, decomposition of thiourea and production of sulphate and acid. Aeration also promoted growth and sulphate production. Among the incompletely oxidized decomposition products were sulphate esters and ureides.

Sulphate production indicated that thiourea and four substituted thioureas underwent slow decomposition in soil and sewage sludge. In soil, all of the sulphur of the compounds was oxidized to sulphate in 20 weeks; decomposition was much slower in sewage sludge. Most cultures isolated from treated soil and sewage sludge failed to attack thiourea in culture media on serial transfer.
\end{abstract}

\section{INTRODUCTION}

According to available evidence, thiourea decomposes slowly in soil and animal manure with production of sulphate and ammonia (Fuller, Caster \& McGeorge, I950; Frederick, Starkey \& Segal, 1957; Jensen \& Bendixen, 1958; Stotzky \& Norman, I96I). Its toxicity is attested by the fact that thiourea reduced the microbial population of a soil more than $99 \%$ at a concentration of I \% (Frederick et al. I957). Negligible amounts of thiourea decomposed in sewage sludge during normal retention time (Malaney, Lutin, Cibulka \& Hickerson, 1967) but some decomposition was noted in acclimatized sludge (Downing, Tomlinson \& Truesdale, I964).

The nitrification process is particularly sensitive to thiourea, more so than ammonification (Fuller et al. I950; Quastel \& Scholefield, I95I; Jensen \& Sorensen, I952; Lees, I952; Jensen \& Bendixen, I958; Jaques, Robinson \& Chase, I959; Downing et al. I964; Tomlinson, Boon \& Trotman, I966). Because of their toxicity to various

\footnotetext{
* Present address: Research Laboratories, Rohm and Haas Company, Spring House, Pennsylvania 19477 , U.S.A.
} 
micro-organisms (Nicholas \& Nicholas, 1925; Nicholas \& Lebduska, 1928) thioureas have potentialities as germicides (Weuffen, Göckeritz \& Pohloudek-Fabrini, 1967). Furthermore, thiourea has been proposed as a larvicide in manure (Jensen, I957; Jensen \& Bendixen, 1958), as a soil disinfectant (Frederick et al. 1957), and as a fertilizer with slowly available nitrogen (Fuller et al. 1950). Thiourea inhibits certain enzymes (Landon, 1934; Mayer, I958; Bouchilloux, 196I ; Yamafuji \& Osajima, I96I). Since it is a strong chelating agent (Boeyens \& Herbstein, I966) its toxicity to micro-organisms and inhibition of enzyme action may be due, at least in part, to its chelation of heavy metals.

Little is known about the micro-organisms which attack thiourea or the products formed. Rippel (1925) reported that a small amount of sulphate was produced by Aspergillus niger. The most detailed results were obtained by Jensen (1957), who isolated fungi from soil which used thiourea as a source of sulphur and nitrogen when grown in a glucose medium. The two most active fungi converted I5 and $17 \%$ of the thiourea sulphur to sulphate in 50 days. Less than half of the thiourea nitrogen had become assimilated on prolonged incubation when practically all of the thiourea had disappeared; the greater part of the nitrogen was unaccounted for.

Herein are reported results of studies on the decomposition of thiourea by a fungus isolated from soil, the influence of certain cultural conditions on the breakdown, the sulphur and nitrogen products formed, and the course of events in dissimilation of the compound. Included also are results of study of the decomposition of various thioureas in soil and by micro-organisms in sewage sludge.

\section{Cultural}

\section{METHODS}

Pure cultures in $250 \mathrm{ml}$. Erlenmeyer flasks were shaken at $28^{\circ}$ on a rotary shaker ( 240 to $280 \mathrm{cyc} . / \mathrm{min}$.) in $100 \mathrm{ml}$. of: glucose, $20 \mathrm{~g}$. (sterilized separately); thiourea, $0.25,0.50$ or $\mathrm{I} .00 \mathrm{~g}$. $\mathrm{K}_{2} \mathrm{HPO}_{4}, \mathrm{I} .5 \mathrm{~g} . ; \mathrm{KH}_{2} \mathrm{PO}_{4}, 0.75 \mathrm{~g} . ; \mathrm{CaCl}_{2} .2 \mathrm{H}_{2} \mathrm{O}$, 0.05 g.; $\mathrm{MgCl}_{2} \cdot 6 \mathrm{H}_{2} \mathrm{O}$, 0.08 g.; $\mathrm{FeCl}_{3} \cdot 6 \mathrm{H}_{2} \mathrm{O}$, 0.01 g.; dist. $\mathrm{H}_{2} \mathrm{O}$ to $1000 \mathrm{ml}$., pH $7 \cdot 0$. Other organic compounds sometimes replaced glucose; phosphate buffer and thiourea concentrations sometimes differed (see Results).

The stock of Penicillium was maintained on a similar medium which contained $0.1 \%$ yeast extract, $0.05 \%$ thiourea and $2 \%$ agar. Pure culture inoculum contained $2 \times 10^{6}$ conidia in $0.5 \mathrm{ml}$. sterile water. After incubation the fungus was filtered off, washed, dried and weighed. The culture solution was brought to volume for analyses.

Decomposition of thioureas in $200 \mathrm{~g}$. portions of barnyard soil was tested at 0.02 and $0 . \mathrm{I} \mathrm{M}$. Glucose $(0.5 \%)$ was added to soil with and without thioureas. The moisture content was brought to $50 \%$ of the moisture-holding capacity, and water was added periodically to maintain the moisture level during incubation at $28^{\circ}$ for several weeks. For tests with activated sludge, $10 \mathrm{ml}$. portions were added to $90 \mathrm{ml}$. of a mineral salts medium containing $0.5 \%$ glucose and thioureas at 0.02 and $0 . \mathrm{I} \mathrm{M}$.

\section{Analytical}

Sulphate was determined on soil extracts prepared by a procedure adapted from Chesnin \& Yien (1950) and Bartlett \& Neller (1960): a $50 \mathrm{ml}$. flask containing $5 \mathrm{~g}$. of soil and $20 \mathrm{ml}$. aqueous $10 \%$ sodium acetate $+3 \%$ glacial acetic acid was shaken mechanically for $30 \mathrm{~min}$. and centrifuged. After $\mathrm{I} \cdot 2 \mathrm{~g}$. of 20 to $30 \mathrm{mesh}$ crystals of 
$\mathrm{BaCl}_{2}$ had been added to $10 \mathrm{ml}$., the material was shaken $30 \mathrm{~min}$. and the turbidity due to $\mathrm{BaSO}_{4}$ measured by a nephelometer. Correction was made for colour of the extracts. For culture filtrates, $0.5 \mathrm{ml}$. of $\mathrm{I} 2 \%(\mathrm{w} / \mathrm{v}) \mathrm{HCl}$ was added to 4 or $8 \mathrm{ml}$. filtrate in a $50 \mathrm{ml}$. Erlenmeyer flask, made up to $40 \mathrm{ml}$. with distilled water and $4.8 \mathrm{~g}$. of 20 to 30 mesh crystals of barium chloride added. The mixture was shaken intermittently for $20 \mathrm{~min}$. and turbidity measured in a Klett colorimeter using a rectangular glass cell (40 mm. outside diam.). No stabilizer was needed to hold the precipitate in suspension, and the thiourea did not interfere with the determination. Corrections were made for colour and turbidity of the culture filtrates.

Thiourea was determined colorimetrically using Grote's reagent (Anonymous, I960). Values were accurate from 25 to $200 \mu \mathrm{g}$. thiourea. Total nitrogen was determined by a micro-Kjeldahl method (Colowick \& Kaplan, I955-7), ammonium nitrogen by titration of the distillate of the culture solution made alkaline with $\mathrm{NaOH}$ or $\mathrm{MgO}$, and glucose by use of anthrone reagent (Umbreit, Burris \& Stauffer, I957). Amino nitrogen was measured colorimetrically according to Danielson (1933) and Hotchkiss (I956). Urea was determined by microdiffusion with urease (Conway, 1950). The colorimetric procedure of Koritz \& Cohen (1954) as modified by Bojanowski, Goudy, Valentine $\&$ Wolfe (1964) was used to detect ureido compounds. Test for hydroxylamine was made by a method of Czaky (1948) as modified by Klein \& Pramer (I962), and for thiocyanate according to Colowick \& Kaplan (1955-7). Sulphate released from ethereal sulphates (Colowick \& Kaplan, 1955-7) was determined as barium sulphate. Tests were made also for methylthio groups (Segal \& Starkey, 1969) and sulphydryl groups (Colowick \& Kaplan, 1955-7), and for thiosulphate and polythionates (Starkey, 1934).

\section{RESULTS}

\section{Isolation and characterization of a thiourea-decomposing culture}

One of the crude cultures which developed from an inoculum of thiourea-treated soil produced a substantial amount of sulphate in a few weeks in glucose-thiourea medium. A fungus isolated from this culture developed well and produced sulphate in an aerated glucose-thiourea medium with thiourea as the only source of nitrogen and sulphur. Glucose or its equivalent was required as a source of energy and probably of carbon. Thus the transformation appears to be another example of codissimilation (Ruiz-Herrera \& Starkey, I969). The fungus which was used in the following experiments was identified as Penicillium species of the group Biverticillata-Symmetrica. It resembled Penicillium rugulosum (Raper \& Thom, 1949).

\section{Transformation of thiourea by Penicillium}

The fungus developed well initially in the basal medium containing glucose and 0.025 and $0.05 \%(\mathrm{w} / \mathrm{v})$ thiourea, but it grew slowly in the presence of $0.10 \%$ thiourea and failed to grow at $0.20 \%$. On repeated subculture the fungus developed tolerance to increased concentrations of thiourea.

Fig. I illustrates changes which were obtained with $0.05 \%(\mathrm{w} / \mathrm{v})$ thiourea; similar changes occurred with 0.025 or $0.01 \%$ thiourea. The log phase extended from the second to the fifth day. The medium became strongly acid and the principal drop in $\mathrm{pH}$ occurred during the lag phase. By the end of the lag phase all of the thiourea had disappeared and the sulphate content was nearly maximum. After incubation, only $3 \mathrm{I} \%$ of the thiourea sulphur was present as sulphate and $7 \%$ of the thiourea nitrogen 
as ammonia. Thirty-three per cent of the nitrogen had been assimilated but $60 \%$ was unaccounted for. The sulphur and nitrogen not accounted for in this and other experiments probably were present as intermediate products.

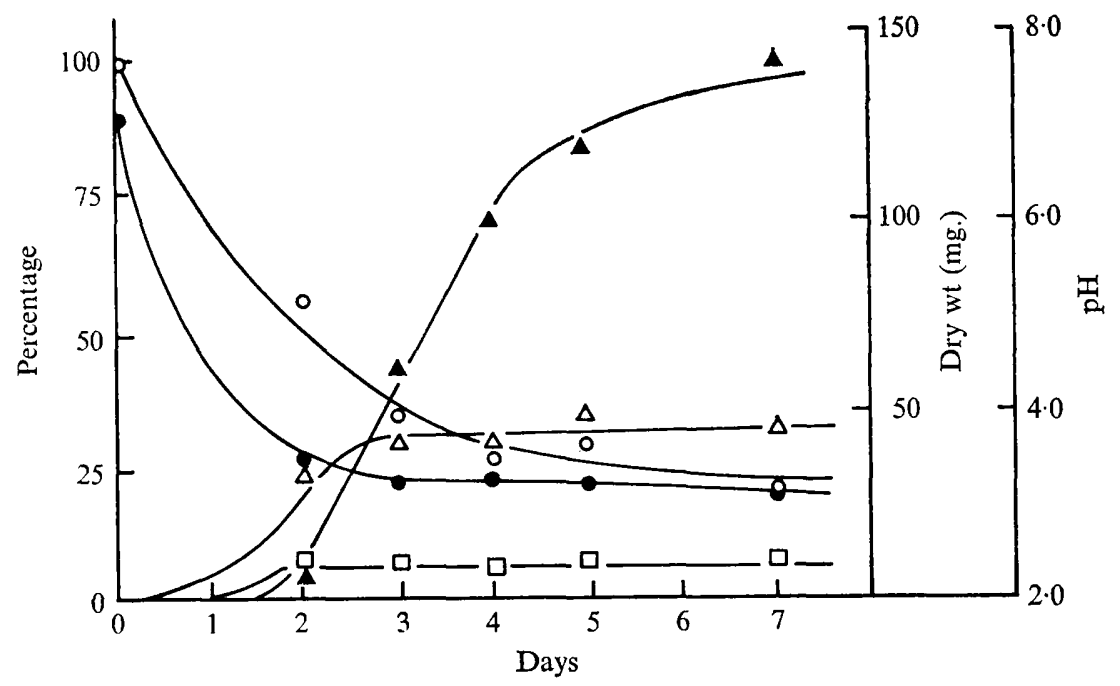

Fig. I. Changes occurring during transformation of thiourea at $28^{\circ}$ by Penicillium. For medium and conditions, see text. $O,(\%, w / v)$ Glucose; $\triangle$, sulphatesulphur ( $\%$ of initial thiourea sulphur); $\square$, ammonium nitrogen (\% of initial thiourea nitrogen); $\mathbf{e}, \mathrm{pH} ; \mathbf{\Delta}$, growth.

Table I. Influence of shaking on breakdown of thiourea by a Penicillium

Cultures incubated 6 days at $28^{\circ}$, for details see text.

$\begin{array}{cccccc}\begin{array}{c}\text { Condition of } \\ \text { incubation }\end{array} & \mathrm{pH} & \begin{array}{c}\text { Dry wt of } \\ \text { fungus (mg.) }\end{array} & \begin{array}{c}\text { Thiourea } \\ \text { decomposed } \\ (\%)\end{array} & \begin{array}{c}\mathrm{SO}_{4}^{-}-\mathrm{S}, \% \\ \text { of initial } \\ \text { thiourea-S }\end{array} & \begin{array}{c}\mathrm{NH}_{4}^{+}-\mathrm{N}, \% \\ \text { of initial } \\ \text { thiourea-N }\end{array} \\ \begin{array}{c}\text { Static } \\ \text { Shaken }\end{array} & 4 \cdot 6 & 10 & 91 & 13 & 22 \\ & 3 \cdot 4 & 82 & 9 \mathrm{I} & 32 & \mathbf{1 2}\end{array}$

\section{Some growth requirements}

In media prepared with 'reagent grade' salts, the fungus required added magnesium but not calcium, iron, sodium, zinc or manganese. Copper (14 $\mu \mathrm{g} . / \mathrm{ml}$.) was toxic but its toxicity was overcome by citrate in a medium containing $0.05 \%(\mathrm{w} / \mathrm{v})$ thiourea but not in one with $0.1 \%$. Yeast extract $(50 \mu \mathrm{g} . / \mathrm{ml}$.) increased the amount of growth in 3 days but had no significant effect subsequently. None of nine vitamins increased the amount of growth in 3 and 7 days in the glucose-thiourea medium. The fungus decomposed thiourea in both static and shaken media but more mycelium and more sulphate appeared in shaken media (Table I). This suggests that the reactions responsible for formation of sulphate were more sensitive to oxygen tension than those effecting the initial transformation of thiourea.

\section{Replacement of thiourea}

In media containing ammonium sulphate as nitrogen + sulphur source, but no thiourea, the fungus grew well on glucose, fructose, galactose, mannitol, ethanol and 
acetate, but only slightly on sorbitol, succinate, or citrate. Only glucose supported good growth with thiourea, which suggests that thiourea either inhibited uptake of the unutilized compounds or blocked their conversion to assimilable substances.

\section{Influence of the nitrogen source on growth and on breakdown of thiourea}

The following compounds, listed in the order in which they promoted growth, served as sources of nitrogen (at $18.4 \mathrm{mg}$. N/100 ml.) in a glucose medium: ammonium sulphate, glycine $>$ potassium nitrate $>$ oxamic acid $>$ thiourea. The mycelial dry wt with $\mathrm{NH}_{4}$ was more than twice that with thiourea. Jensen (r957) noted also that ammonium nitrogen was preferable to thiourea as the source of nitrogen for cultures

Table 2. Influence of ammonia and nitrate on fungus growth and decomposition of thiourea

Cultures shaken 7 days at $28^{\circ}$, for details see text.

$\begin{array}{lcccc}\text { Source of nitrogen (mg.) } & \begin{array}{c}\text { Dry wt of } \\ \text { fungus (mg.) }\end{array} & \begin{array}{c}\mathrm{N} \text { in cell } \\ \text { material (mg.) }\end{array} & \begin{array}{c}\text { Thiourea } \\ \text { decomposed } \\ (\%)\end{array} & \begin{array}{c}\text { Thiourea-S } \\ \text { converted to } \\ \text { sulphate (\%) }\end{array} \\ \text { Thiourea, 52 } & \text { II6 } & 5 \cdot 8 & 98 & 50 \\ \text { Thiourea, 26+ } \mathrm{NH}_{4} \mathrm{Cl}, 39 & 199 & 8 \cdot 6 & 51 & 7 \\ \text { Thiourea, 26+ } \mathrm{KNO}_{3}, 50 & 105 & 4.8 & 97 & 76\end{array}$

Table 3. Effect of ammonia and nitrate on transformation of thiourea nitrogen by Penicillium

Incubated 7 days at $28^{\circ}$, for details see text.

\begin{tabular}{|c|c|c|c|}
\hline \multirow[b]{2}{*}{ Distribution of nitrogen (mg.) } & \multicolumn{3}{|c|}{ Source of $N$} \\
\hline & Thiourea & $\begin{array}{c}\text { Thiourea } \\
\mathrm{NH}_{4} \mathrm{Cl}\end{array}$ & $\begin{array}{c}\text { Thiourea }+ \\
\mathrm{KNO}_{3}\end{array}$ \\
\hline \multicolumn{4}{|l|}{ Uninoculated control } \\
\hline Thiourea & $19 \cdot 2$ & $9 \cdot 4$ & $9 \cdot 4$ \\
\hline Nitrate & - & - & $7 \cdot 0$ \\
\hline Ammonia & - & $8 \cdot 3$ & - \\
\hline \multicolumn{4}{|l|}{ Inoculated media } \\
\hline Mycelium & $5 \cdot 8$ & $8 \cdot 6$ & $4 \cdot 8$ \\
\hline Filtrate & $12 \cdot 2$ & $9 \cdot 8$ & II $\cdot 8$ \\
\hline $\mathrm{N}$ accounted for & $18 \cdot 0$ & $18 \cdot 4$ & $16 \cdot 6$ \\
\hline Ammonia & $2 \cdot 4$ & 0.6 & 0.8 \\
\hline Nitrate & - & - & $7 \cdot 0$ \\
\hline Thiourea & 0.3 & $4 \cdot 5$ & 0.3 \\
\hline $\begin{array}{l}\mathrm{N} \text { in filtrate other } \\
\text { than } \mathrm{NH}_{4}^{+}, \mathrm{NO}_{3}^{-} \\
\text {and thiourea }\end{array}$ & $9 \cdot 5$ & $4 \cdot 7$ & $3 \cdot 7$ \\
\hline
\end{tabular}

of fungi that decomposed thiourea. There was little or no growth with the following sources of nitrogen: cyanamide, potassium thiocyanate, thiosemicarbazide, ethylenediamine dihydrochloride, potassium ferrocyanide, diethylthiourea, dibutylthiourea, phenylthiourea, benzylpseudothiourea.

When approximately equal amounts of nitrogen were supplied as thiourea $(0.025 \%)$ and ammonium chloride, the fungus made more growth and assimilated more nitrogen than when all nitrogen was provided as thiourea (Table 2). Ammonium, but not nitrate, nitrogen had an inhibitive effect on decomposition of thiourea and on conversion 
of the thiourea sulphur to sulphate. Nearly all of the thiourea disappeared from culture solutions which contained thiourea or thiourea + nitrate as the nitrogen sources, and conversion of the thiourea sulphur to sulphate was greater in the latter. Table 3 shows that practically all the nitrogen provided as ammonium chloride was assimilated, but one-half of the thiourea remained at the end of incubation. Nitrate was not assimilated if the medium contained thiourea. The inhibitive effect of thiourea on nitrate assimilation may have been due to its toxicity to nitrate reductase (Yamafuji \& Osajima, I96r).

\section{Influence of reaction on decomposition of thiourea}

The reaction became strongly acid during development of the fungus in media containing glucose and thiourea. Although some of the acidity was due to sulphate production, most is ascribed to products of glucose breakdown because the change in $\mathrm{pH}$ was approximately the same with and without thiourea. The organic acids were not identified, but chromatographic tests excluded formic, acetic, lactic, malonic, oxalic, succinic and citric acids. With the solvent system $n$-butyl alcohol-acetic acidwater (120:30:50) a strong yellow spot developed with bromocresol green at $\boldsymbol{R}_{\boldsymbol{F}} 0.05$ to 0.07 and a weak one at $R_{F} 0.20$ to 0.25 .

When the $\mathrm{pH}$ of a medium containing, for example, $0.05 \%(\mathrm{w} / \mathrm{v})$ thiourea was controlled by periodic neutralization with $\mathrm{NaOH}$, the thiourea sulphur oxidized to sulphate increased from 37 to $65 \%$. In other experiments in which the $\mathrm{pH}$ was partly or largely controlled, oxidation of from 80 to $100 \%$ of the thiourea sulphur to sulphate took place (Table 4). All thiourea had disappeared from these media and the mycelial dry weights were approximately the same. Only a small portion of the thiourea nitrogen was recovered as ammonia.

Table 4. Influence of reaction on decomposition of thiourea by Penicillium

Incubated 7 days at $28^{\circ} . \mathrm{pH}$ change restricted by increased phosphate buffer or, for last two entries, periodic additions of $\mathrm{NaOH}$.

$\begin{array}{cccc}\text { Buffer (M) } & \text { Final pH } & \begin{array}{c}\mathrm{NH}_{4}^{+}-\mathrm{N}, \% \\ \text { of added } \\ \text { thiourea-N }\end{array} & \begin{array}{c}\mathrm{SO}_{4}^{-}-\mathrm{S}, \% \\ \text { of added } \\ \text { thiourea-S }\end{array} \\ 0.014 & 3.3 & 22 & 33 \\ 0.035 & 3.5 & \text { II } & 45 \\ 0.042 & 4.0 & 19 & 64 \\ 0.070 & 4.5 & 8 & 100 \\ 0.014 & 7.0 & 19 & 78 \\ 0.042 & 6.6 & 17 & 86\end{array}$

\section{Effect of glucose concentration on decomposition of thiourea}

Fig. 2 shows that increased glucose led to increased growth, thiourea decomposed, sulphate produced and acid. Conversion of thiourea sulphur to sulphate reached a maximum of $72 \%$ with $2 \%(w / v)$ glucose. Irrespective of glucose concentration only a small amount of the thiourea nitrogen was converted to ammonia, the maximum being approximately $12 \%$. The relatively high buffer content prevented extreme drop in $\mathrm{pH}$; except with $2 \%(\mathrm{w} / \mathrm{v})$ glucose, the reaction remained above $\mathrm{pH} 5.0$. In similar experiments with $0.014 \mathrm{M}$-phosphate buffer, the $\mathrm{pH}$ dropped to much lower levels and the conversion of the thiourea sulphur to sulphate was much lower. All of the thiourea 
disappeared from the medium which contained $2 \%(w / v)$ glucose. In another experiment, the amounts of fungus and of thiourea transformed were similar with 2 and $3 \%$ glucose.

\section{Breakdown of thiourea by pregrown mycelium}

Mycelium from thiourea media with various concentrations of glucose and phosphate and with either organic or inorganic sources of nitrogen was harvested during the $\log$ phase. It was washed and suspended in 0.014 to $0.042 \mathrm{M}$-potassium phosphate buffer, $\mathrm{pH} 7.0$ or 5.5 , containing $0.0 \mathrm{I}$ or $0.05 \%(\mathrm{w} / \mathrm{v})$ thiourea. Glucose was present in some media and absent from others. Tests were made for disappearance of thiourea and for production of sulphate and ammonia between 3 to $10 \mathrm{~h}$., and in one experiment at $72 \mathrm{~h}$. In no case was there rapid and complete breakdown of thiourea.

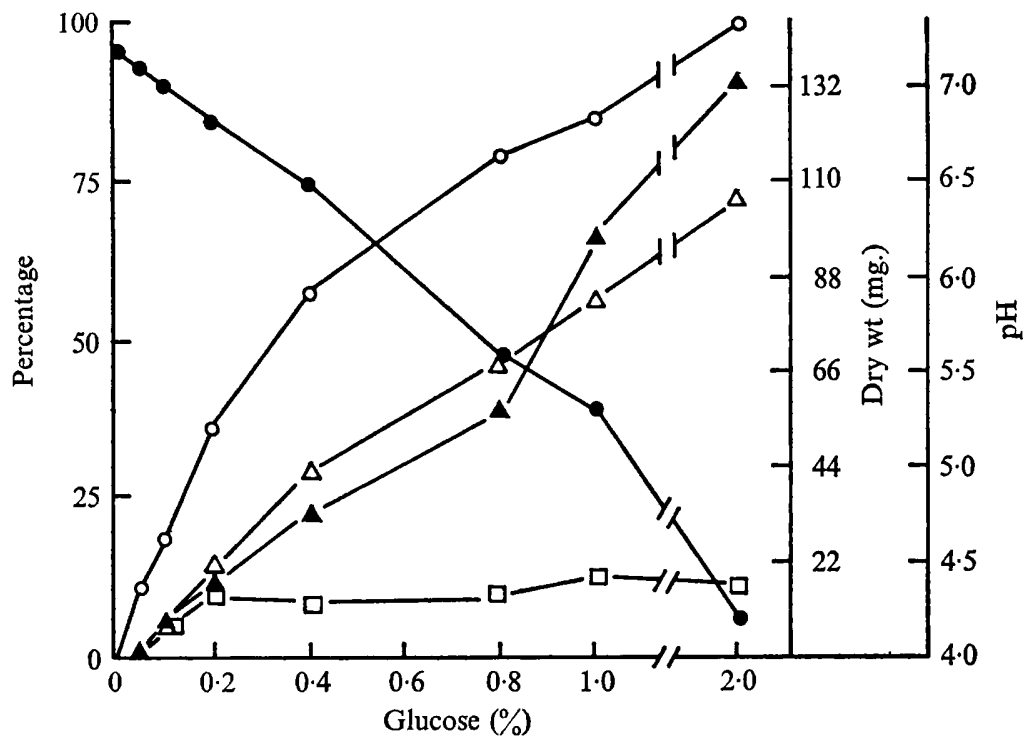

Fig. 2. Effect of glucose concentration on transformation of thiourea by Penicillium after 6 days at $28^{\circ}$; initial pH 7.2; thiourea $0.05 \%$; phosphate buffer $0.042 \mathrm{M}$. O, Loss of thiourea $(\%) ; \triangle$, increase in sulphate sulphur ( $\%$ of initial thiourea sulphur); $\square$, increase in ammonium nitrogen (\% of initial thiourea nitrogen);, $\mathrm{pH} ; \boldsymbol{\Delta}$, growth.

\section{Products of thiourea dissimilation}

The only sulphur product identified was sulphate. Other sulphur products must have been formed because only 30 to $50 \%$ of the sulphur of the decomposed thiourea appeared as sulphate in some experiments. Filtrate of a culture with $0.05 \%(\mathrm{w} / \mathrm{v})$ thiourea and $0.042 \mathrm{M}$-phosphate buffer, $\mathrm{pH} 7.0$, incubated 7 days, contained $19 \%$ of the thiourea sulphur as ethereal sulphate and $46 \%$ as sulphate. The identity of the thioether(s) was not established. Compounds with methylthio groups, hydrosulphide groups, thiosulphate, polythionates and hydrogen sulphide were absent.

Ammonia was the only nitrogen product identified. Considerable amounts of nitrogen were assimilated but almost half of the thiourea nitrogen was unidentified material. The culture filtrate from glucose-thiourea media gave a strong positive test for ureido compounds; these were absent from uninoculated thiourea media and from filtrates 
of fungus cultured with ammonium sulphate in place of thiourea. Ureido compounds were absent also in culture solutions containing urea, amino nitrogen, primary amines, free and bound hydroxylamines, thiocyanate, biuret, nitrite and nitrate.

\section{Decomposition of thioureas by natural microbial populations}

Production of sulphate served as the index of thiourea decomposition. All of the compounds underwent decomposition in soil (Table 5) but the breakdown was slow. At the lower concentration of the thioureas there was appreciable decomposition in I week and most of the sulphur became transformed to sulphate in I 5 weeks. Dibutylthiourea decomposed slowest but all of its sulphur was converted to sulphate in 20 weeks. With 0.1 M-thioureas the percentage conversions of sulphur were much lower, but the actual amounts converted were similar to those at $0.02 \mathrm{M}$. Decomposition of the thioureas other than benzylthiopseudourea had comparatively little effect on $\mathrm{pH}$ of the soil.

Decomposition of the thioureas by the micro-organisms in activated sludge was much slower than by those in soil (Table 6). Even at the lower concentration, the maximum sulphur conversion in 20 weeks was $22 \%$.

\section{Table 5. Production of sulphate from thioureas in soil}

Initial $\mathrm{pH}$ of soil was 8.5 ; sulphate analyses corrected for sulphate in untreated soil. For details see text.

Compound

None

Thiourea

Diethylthiourea

Dibutylthiourea

Phenylthiourea

Benzylthiopseudourea
(M)

$\overbrace{\text { I week } 2 \text { weeks } 15 \text { weeks }}^{\mathrm{pH} \text { after }}$

$\% \mathrm{~S}$ recovered as sulphate after

$\overbrace{\text { I week } 2 \text { weeks } 15 \text { weeks }}$

\begin{tabular}{rrr}
\hline 22 & & - \\
\cline { 2 - 3 } 4 & 27 & 96 \\
40 & 4 & 28 \\
4 & 40 & 91 \\
19 & 3 & 12 \\
4 & 26 & 56 \\
$4 I$ & 5 & 12 \\
8 & 45 & 107 \\
25 & 10 & 26 \\
1 & 44 & 93 \\
1 & 3 & 45
\end{tabular}

Table 6. Production of sulphate from thiourea in sewage sludge

Initial $\mathrm{pH} 7 \cdot 0$; culture $\mathrm{pH}$ kept neutral during incubation by periodic additions of $\mathrm{NaOH}$. $\mathrm{SO}_{4}^{=}$values corrected for content of controls. For details see text.

\begin{tabular}{|c|c|c|c|c|c|c|c|}
\hline \multirow[b]{2}{*}{ Compound } & \multirow[b]{2}{*}{ (M) } & \multicolumn{3}{|c|}{$\mathrm{pH}$ after } & \multicolumn{3}{|c|}{$\% \mathrm{~S}$ recovered as sulphate after } \\
\hline & & 5 weeks & 10 weeks & 20 weeks & 5 weeks & Io weeks & 20 weeks \\
\hline Thiourea & 0.02 & $7 \cdot 1$ & $7 \cdot 0$ & $7 \cdot 1$ & 6 & 8 & I4 \\
\hline & $0 \cdot 10$ & $7 \cdot 6$ & $7 \cdot 3$ & $7 \cdot 4$ & $\mathbf{I}$ & I & 2 \\
\hline Diethyl- & 0.02 & $7 \cdot 6$ & $7 \cdot 3$ & $7 \cdot 2$ & 5 & 5 & 13 \\
\hline thiourea & 0.10 & $7 \cdot 9$ & $7 \cdot 8$ & $7 \cdot 6$ & I & I & 3 \\
\hline Dibutyl- & 0.02 & $7 \cdot 7$ & $7 \cdot 5$ & $7 \cdot 2$ & 3 & 3 & 14 \\
\hline thiourea & 0.10 & $7 \cdot 4$ & $7 \cdot 4$ & $7 \cdot 1$ & 2 & 2 & 6 \\
\hline Phenyl- & 0.02 & $7 \cdot 2$ & $7 \cdot 1$ & $7 \cdot 0$ & 3 & 8 & 22 \\
\hline thiourea & 0.10 & $6 \cdot 9$ & $6 \cdot 8$ & $7 \cdot 0$ & $<1$ & $<1$ & 3 \\
\hline Benzylthio- & 0.02 & $6 \cdot 9$ & 6.6 & $6 \cdot 6$ & 0 & 0 & 5 \\
\hline pseudourea & 0.10 & $6 \cdot 3$ & $5 \cdot 8$ & $5 \cdot 5$ & 0 & 0 & 0 \\
\hline
\end{tabular}




\section{Isolation of thiourea-decomposing micro-organisms}

Dilutions of the soils and solutions containing activated sludge, which had been treated with the thioureas, were plated on agar media modified to contain $0.1 \%$ of the same thiourea as the inoculum source, without and with glucose (0. I \%). Most of the colonies which developed were bacteria, but there were some streptomycetes and filamentous fungi. Growth was slight in media without glucose.

Thirty representative cultures isolated from the plates were inoculated into liquid media containing the appropriate thioureas with and without glucose ( $1 \cdot 0 \%$ ). Although there was slight growth of some cultures lacking glucose, no sulphate was produced and the cultures failed to develop on serial transfer. Most isolates grew well with glucose and the thioureas but, with few exceptions, none produced sulphate. One culture, a species of the fungus Cephalosporium, produced some sulphate from benzylthiopseudourea in a glucose-containing medium. During growth, the odour of the compound disappeared from the inoculated medium whereas it persisted in the uninoculated one. Thus few micro-organisms seem able to decompose thiourea.

\section{DISCUSSION}

In studies by Jensen (1957), $20 \%$ or less of the thiourea sulphur was converted to sulphate by certain fungi growing in a medium which contained $2 \%(\mathrm{w} / \mathrm{v})$ glucose and $0.05 \%$ thiourea. The low production of sulphate may have been due to a $\mathrm{pH}$ effect. We noted that the reaction became strongly acidic during breakdown of thiourea and that the acidity impeded conversion of the thiourea sulphur to sulphate. Nevertheless it did not affect the disappearance of the thiourea appreciably.

Sulphate ester(s) was an important sulphur product, particularly in culture solutions which became strongly acid. The fact that the culture solutions gave a strong reaction for ureido compounds suggests that they were the major nitrogen-containing decomposition products. Some ammonium nitrogen was present in culture solutions even when conditions suggested that nitrogen was a limiting factor for growth. Therefore, thiourea or its decomposition products may have interfered with assimilation of nitrogen. Furthermore, even though citrate failed to support growth when it was the only source of energy in a thiourea medium, it promoted growth in a similar medium which contained glucose; a medium with $\mathrm{I} \cdot 5 \%$ (w/v) glucose and $0.5 \%$ sodium citrate yielded approximately twice as much growth as one with $2 \%$ glucose. It seems likely that citrate neutralized some inhibitive effect of thiourea on nitrogen assimilation.

The data are insufficient to establish the course of events in the dissimilation of thiourea but the detection of ethereal sulphate and ureido compounds as products suggests the scheme in Fig. 3. This assumes that the sulphur of the thiourea became transformed to a hydrosulphide and that the sulphur became oxidized to a sulphate ester which was desulphurated to yield sulphate. The urea produced by desulphuration of the thiourea could have been transformed by a process reported by Cook \& Boulter (1964) for Candida flareri. This involved combination of the urea with a 2-carbon unit to give hydantoic acid which became converted to its anhydride, hydantoin, or to glycine and a carbamate. In addition to the ureido compounds, hydantoic acid and hydantoin, the carbamyl compound $\mathrm{R}^{\prime}$. CO. $\mathrm{NH}_{2}$ would react as a ureide if the carbon chain of $R^{\prime}$ was short (Koritz \& Cohen, 1954). Glucose would have provided the 
2-carbon unit. The glycine could have been partly assimilated and partly deaminated to yield ammonia. The residual nitrogen other than ammonia in the culture solution could have been accounted for as the two ureides and the carbamate.

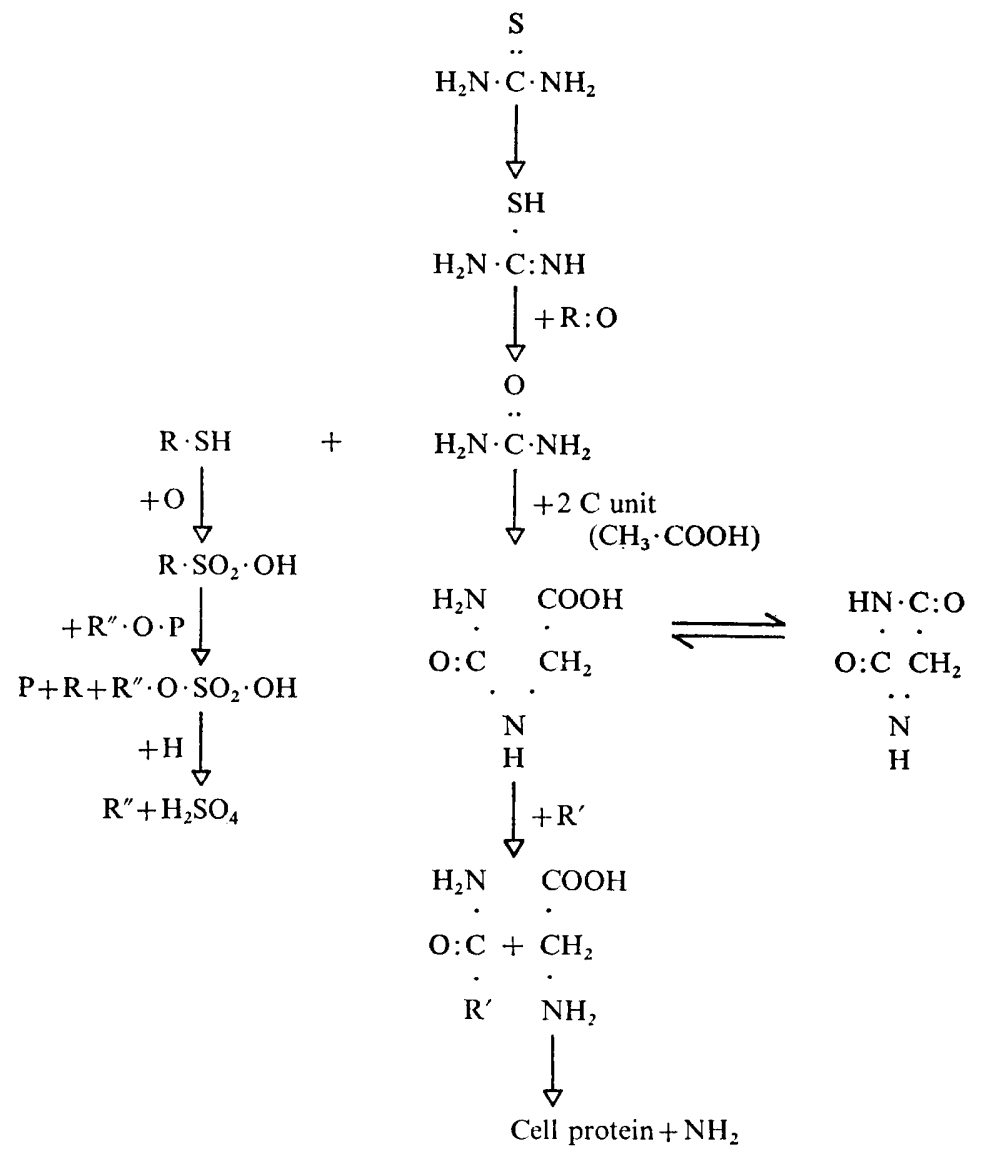

Fig. 3. Proposed scheme of the course of dissimilation of thiourea.

Paper of the Journal Series, New Jersey Agricultural Experiment Station, New Brunswick, N.J., U.S.A.

This project was supported in part by U.S. Public Health Research Grant WP-6, project 309 .

\section{REFERENCES}

Anonymous. (1960). Official Methods of Analysis, 9th edn, pp.40I-403. Washington, D. C.: Association of Official Agricultural Chemists.

Bartlett, F. D. \& Neller, J. R. (1960). Turbidimetric determination of sulphate in soil extracts. Soil Science 90, 20I-204.

Bozyens, J. C. A. \& HerbsteIn, F. H. (1966). Ionic complexes of thiourea. Nature, London 2II, 588590.

Bojanowski, R., Gaudy, E., Valentine, R. C. \& Wolfe, R. S. (I964). Oxamic transcarbamylase of Streptococcus allantoicus. Journal of Bacteriology 87, 75-80. 
Bouchilloux, S. (1961). Action de la polyphénoloxydase en présence de thiourée; inhibition et formation de thioéthers. Comptes rendu des séances de la Société de biologie, Paris 155, 1325-1330.

CHESNIN, L. \& YIEN, C. H. (1950). Turbidimetric determination of available sulphates. Proceedings. Soil Science Society of America 15, I49-I 5 I.

Colowick, S. P. \& KaPlan, N. O. (1955-7). Methods in Enzymology, vol. 2, pp. 334-337, 752; vol. 3, pp. 98I-984, 987-988, 990-100I. New York: Academic Press.

Conway, E. J. (1950). Microdiffusion Analysis and Volumetric Error. London: Crosby Lockwood \& Son Ltd.

Cook, A. R. \& Boulter, D. (1964). Utilization of urea by Candida flareri. Phytochemistry 3, 31 3-319.

CZAKY, T. Z. (1948). On the estimation of bound hydroxylamine in biological materials. Acta chemica scandinavica 2, 450-454.

Danielson, I. S. (1933). Amino acid nitrogen in blood and its determination. Journal of Biological Chemistry ror, 505-522.

Downing, A. L., Tomlinson, T. G. \& Truesdale, G. A. (1964). Effect of inhibitors on nitrification in the activated sludge process. Journal and Proceedings of the Institute for Sewage Purification, pp. 537-554.

Frederick, L. R., Starkey, R. L. \& Segal, W. (I957). Decomposability of some organic sulphur compounds in soil. Proceedings. Soil Science Society of America 2r, 287-292.

Fuller, W. H., CASTER, A. B. \& MCGEORGE, W. T. (I950). Behaviour of nitrogenous fertilizers in alkaline calcareous soils. I. Nitrifying characteristics of some organic compounds under controlled conditions. Technical Bulletin. Arizona Agricultural Experiment Station 120, 45I-467.

Hотснкіss, R. D. (1956). The assimilation of amino acids by respiring washed staphylococci. Archives of Biochemistry and Biophysics 65, 302-318.

JAQUes, R. P., Robinson, J. B. \& CHASE, F. E. (1959). Effects of thiourea, ethyl urethane and some dithiocarbamate fungicides on nitrification in Fox sandy loam. Canadian Journal of Soil Science 39, 235-243.

JeNSEN, H. L. (I957). Biological transformation of thiourea. Archiv für Mikrobiologie 28, I45-I 52.

JENSEN, H. L. \& BENDIXEN, E. (1958). Om biologisk virkning og sonderlinging af thiourinstof $\mathrm{i}$ jord og staldgodning. Tidsskrift for Planteavl 62, 499-521.

JENSEN, H. L. \& SoRENSON, H. (1952). The influence of some organic sulphur compounds and enzyme inhibitors on Nitrosomonas europaea. Acta agriculturae scandinavica 2, 295-304.

KLEIN, D. \& PRAMER, D. (1962). Some products of the bacterial dissimilation of streptomycin. Journal of Bacteriology 83, 309-313.

KORITZ, S. B. \& COHEN, P. P. (I954). Colorimetric determination of carbamylamino acids and related compounds. Journal of Biological Chemistry 209, I45-150.

Landon, R. H. (1934). The effect of certain chemicals on the catalase activity in plants. American Journal of Botany 2I, 583-59I.

LEES, H. (1952). The biochemistry of the nitrifying organisms. I. The ammonia-oxidizing system of Nitrosomonas. Biochemical Journal 52, I34-I 39.

Malaney, G. W., Lutin, P. A., Cibulka, J. J. \& Hickerson, L. H. (I967). Resistance of carcinogenic organic compounds to oxidation by activated sludge. Journal of the Water Pollution Control Federation 39, 2020-2029.

MAYER, A. M. (1958). Ascorbic acid oxidase in germinating lettuce seeds and its inhibition. Physiologia plantarum II, 75-83.

NichOLAS, E. \& LeBDUSKA, J. (1928). Étude comparative de l'action de l'urée et de la sulfo-urée sur le développement et la vitalité des bactéries. Comptes rendus hebdomadaires des séances de l'Academie des sciences, Paris 186, 1767-1769.

Nicholas, E. \& Nicholas, G. (1925). Observations sur l'influence de l'urée de la sulfo-urée et de l'allylsulfo-urée sur les végétaux supérieurs. Comptes rendus hebdomadaires des séances de l'Academie des sciences, Paris $\mathbf{1 8 0}$, I286-1289.

QuAstel, J. H. \& SChOlefield, P. G. (I95I). Biochemistry of nitrification in soil. Bacteriological Reviews 15, I-53.

RAPER, K. B. \& THOM, C. (1949). A Manual of the Penicillia. Baltimore, Maryland: Williams and Wilkins Co.

RIPPEL, A. (1925). Notiz über die Verarbeitung von Thioharnstoff durch Aspergillus niger v. Tgh. Biochemische Zeitschrift 165, 473-474. 
Ruiz-Herrera, J. \& StARKey, R. L. (1969). Dissimilation of methionine by fungi. Journal of Bacterio$\log y$ 99, 544-551.

Segal, W \& Starkey, R. L. (1969). Microbial decomposition of methionine and identity of the resulting sulphur products. Journal of Bacteriology 98, 908-913.

StaRkEY, R. L. (I934). The production of polythionates from thiosulfate by micro-organisms. Journal of Bacteriology 28, 387-400.

Stotzky, G. \& Norman, A. G. (196I). Factors limiting microbial activities in soil. II. The effect of sulphur. Archiv für Mikrobiologie 40, 370-382.

Tomlinson, T. G., Boon, A. G. \& Trotman, C. N. A. (1966). Inhibition of nitrification in the activated sludge process of sewage disposal. Journal of Applied Bacteriology 29, 266-29I.

UMBreIt, W. W., Burris, R. H. \& Stauffer, J. F. (I957). Manometric Techniques, 3rd edn, p. 239. Minneapolis, Minnesota: Burgess Publ. Co.

WeUfFen, W., Göckeritz, D. \& PohloudeK-FabrinI, R. (1967). Zusammenhänge zwischen chemischer Konstitution und keimwidriger Wirkung. Pharmazie 22, 506-517.

Yamafuit, K. \& OSAJIMA, Y. (I96I). Ammonia dehydrogenase, hydroxylamine dehydrogenase, hyponitrite dehydrogenase, and nitrite dehydrogenase. Nature, London I9o, 534-353. 